\title{
Szücs Péter
}

\section{Katonai vezetési kultúra a Magyar Honvédségben}

\author{
DOI 10.17047/HADTUD.2021.31.1.21
}

A katonai vezetési kultúra, a katonai vezetés egyik legmeghatározóbb tényezõje, és a minõsége határozza meg a vezetés sikerét. Értéke és erõssége abban rejlik, hogy a vezetõ mennyire hisz benne, és mennyire tudja közvetítetni azt. Amíg a vezetõi gondolkodás egy olyan folyamat, amelynek célja a problémamegoldás és a lehetséges legmegfelelõbb út megtalálása a feladatok rendszerében, addig a vezetõi kultúra egy olyan komplex jelenség, amely magába foglalja azokat az értékeket, amiket a vezetõ a beosztottjaival együtt közösen teremt vagy ápol a saját cél és elöljárói szándék elérése érdekében.

KULCSSZAVAK: katonai vezetõ, vezetõi kultúra, szervezeti kultúra

\section{Military Leadership Culture in the Hungarian Defence Forces}

Military leadership culture is one of the most determining factors of military leadership and its quality stipulates the success of the leadership itself. Its value and strength depends on how much the leader believes in it and his or her capability to transfer it to others. The leadership thinking is a process whose aim is problem solving and finding the most sufficient way in the system of different tasks, while on the other hand, leadership culture is such a complex phenomenon that involves values which are created or cultivated by the leader along with his or her subordinates in order to support the intention of their superior.

KEYWORDS: military leader, military leadership culture, organizational culture

\section{Bevezetés}

A Magyar Honvédség az elmúlt harminc évben tömeghadseregbõl önkéntes haderõvé vált. Ez egy nagyon hosszú és komplex folyamat volt, tele kihívásokkal. A kihívások olyan követelményeket állítottak a teljes haderõvel szemben, amik gyökeresen megváltoztatattak mindent. Változtak a mûködést szabályzó dokumentumok, 
Nemzeti Közszolgálati Egyetem, Hadtudományi Doktori Iskola, doktoranduszhallgató - National University

of Public Service, Doctoral School of Military Sciences; PhD Student; e-mail:szucs.peter2@mil.hu;

https://orcid.org/0000-0003-3026-128X

a szervezeti felépítések, technikai eszközök, valamint ezekkel együtt kellett változni a vezetési rendszereknek, ami a katonai gondolkodás változását is eredményezte. Ebben a harminc évben az egyik legmeghatározóbb esemény a NATO-csatlakozás volt. A magas követelmények és az új kihívások folyamatos részei lettek a mindennapi életnek. A nemzetközi jelenlét és a missziós szerepvállalás lehetõséget adott a katonák számára betekintést nyerni más haderõk mûködésébe, szervezeti felépítésébe és vezetési rendszerébe. A többnemzeti kontingensek mûködése során többre volt szükség, mint egymás megismerésre. Alkalmazni és használni kellett a közös elveket, és megérteni egymást a mûveletek során olyan mélységekig, hogy a kitûzött mûveleti célt közös erõvel legyünk képesek elérni.

Ha a haderõre gondolunk, annak mindig részei lesznek a benne szolgálatot teljesítõ katonák, a technikai eszközök, az eljárásrendek vagy akár a felépítési rendszere. De mi a fõ mozgató rugója ennek a hatalmas szervezetnek? Azok a katonák, akik a szakmai tudásuk legjavát adják a mindennapokban, akik erõn felül teljesítik a szervezeti célok eléréséhez szükséges erõforrás-mozgatásokat, és felelõsséget vállalnak a meghatározott feladatok végrehajtásáért. Vezetik a rájuk bízott katonákat itthon és külföldön egyaránt. Ezek a katonák a katonai vezetõk. Az elmúlt harminc év számukra volt a legmegterhelõbb. Minden változáshoz alkalmazkodni kellett, ami folyamatos tanulást és gondolkodást, magatartásváltozást követelt meg tõlük. A vezetõi gondolkodás gyökeres változása az idõ rohanásával egyre gyorsabb lett. Akik nem tudták vagy nem akarták ezt követni, azok kiestek, vagy kiváltak a rendszerbõl, ezzel alkalmatlanná váltak vezetõnek lenni. A vezetõi gondolkodás fejlõdését meghatározó és befolyásoló tényezõk: a szervezeti és a vezetési kultúra.

\section{Rövid történelmi áttekintés}

Ha arra gondolunk, hogy nemrég ünnepeltük a Magyar Honvédség 170 éves születésnapját, akkor látható, hogy ez milyen hosszú idõ. Hány háború, hány forradalom, mennyi változás, amely befolyásoló tényezõ, ami komoly hatással volt nem csak a katonai, de a civil társadalom életére is. Az Osztrák-Magyar Monarchia idején már nyomokban jelen volt a magyar katonai gondoldásban a porosz vezetési kultúra, ami a küldetésorientált vezetés kialakulásának a bölcsõje. ${ }^{1} \mathrm{~A}$ második világháború végéig ennek jelenléte érezhetõ volt a magyar katonai vezetõi gondolkodásban, különös tekintettel a Horthy idõszakra, de a világháború után megkezdõdött az orosz hatás jelenléte miatt a tömeghadseregre jellemzõ vezetési kultúra felvétele a magyar katonai vezetésben. Az orosz hatás azért volt speciális, mert az õ hagyományaik is a porosz kultúrából erednek, de sajátosan értelmezett és kiegészített változatban. Majd a varsói szerzõdésbõl történõ kiválás a nyitást jelentette, megkezdõdött a Magyar Honvédség béketámogató mûveletekben való részvétele. Kicsivel késõbb a NATOtagság már komoly változást jelentett az új, nagyon magas követelmények

\footnotetext{
${ }^{1}$ Czeglédi 2015, 94.

http://epa.oszk.hu/02400/02463/00028/pdf/EPA02463_hadtudomanyi_szemle_2015_03_089-100.pdf (Letöltés ideje: 2020. 11. 12.)
} 
megjelenése miatt. Eltûnt a tömeghadsereg fogalma, a kötelezõ katonai szolgálatot teljesen felváltotta az önkéntes szolgálatvállalás. A haderõ fejlõdése a nyitás óta eléggé változóan zajlott. Voltak nagyon nehéz idõszakok, olyanok is, amik inkább visszafejlõdésként voltak érzékelhetõek, néhány esetben pedig mindenki a tûzoltás idõszakát élte meg. Az új eszközök megjelenésével, a nemzetközi feladatokban történõ egyre nagyobb létszámú részvétellel és az ezzel járó felelõsséggel kezdett az elismerés is nõni. A jelenleg zajló, minden területet érintõ modernizációs folyamat pedig több mint mérföldkõ a Magyar Honvédség 170 éves történelmében. Egy olyan pont, amire elõdeink egész életükben vártak, egy olyan lehetõség, aminek eredménye egy nagyon modern, jól strukturált, jó vezetéssel rendelkezõ haderõ. Ahogy pedig azt korábban már írtam, ennek az egész folyamatnak a mozgató ereje a katonai vezetõkben van.

\section{Vezetési kultúra és szervezeti kultúra kapcsolata}

A vezetési kultúra fogalmának meghatározására nagyon nehezen találunk bármilyen tanulmányt vagy tudományos kutatást, és ha valaki megemlíti a meghatározást bármilyen tanulmányban, akkor is maximum csak érintõleg foglalkozik vele. Ha azt a pár említést értelmezzük, akkor talán sokan egyszerûen azt gondolják, hogy a vezetési kultúra a szervezeti kultúra kivetülése, vezetõi szinten. Azonban azt gondolom, hogy ezt nem lehet egzakt tényként kezelni. Az alábbiakban elsõként próbálom meghatározni a vezetési kultúra fogalmát, értelmezni összetevõit és definiálni azokat a típusokat, amelyek jelen vannak a Magyar Honvédségben.

A szervezeti kultúra fogalmának nagyon sokféle meghatározása létezik, ezek kutatásonként változnak, és a különbözõ kutatások empirikus eredményei ellentmondásosak. A fogalom kulcsszavai vagy szóösszetételei is változnak, de van pár olyan, amelyik mindegyik megfogalmazásban megtalálható. Eszerint a szervezeti kultúra a szervezet minden tagja által elfogadott, közösen értelmezett, értékek, meggyõzõdések, hiedelmek és ezek összességének a rendszere. Nyilván a megfogalmazások szervezet típusonként változnak, és a szervezetre jellemzõ sajátosságokkal ruházzák fel azokat. Éppen emiatt nehéz a definíció pontos meghatározása. ${ }^{2}$

A szervezeti kultúrát Geert Hofstede, holland kultúrakutató vizsgálta, akinek tudományos eredményei között szerepel a szervezeti kultúra öt dimenziójának, a szervezeti kultúra ideál típusainak és a szervezeti kultúra alapköveinek a meghatározása. „,Geert Hofstede a kultúrát a gondolkodás kollektív programozásaként definiálja, amely kizárólag egy csoportra vagy egy bizonyos kategóriára jellemzõ, $s$ azokat a közös jellemzõket tartalmazza, amelyek a környezet változásaira adott válaszainkat befolyásolják. Kultúra mindaz, amit az emberek tesznek, gondolnak, és amivel rendelkeznek, mint a társadalom tagjai.",3

A vezetéssel kapcsolatosan azt mondja: a vezetés során nem lehet vezetési és szervezeti elméleteket exportálni egy szervezet életébe anélkül, hogy ne vennénk figyelembe a

\footnotetext{
${ }^{2}$ Málovics 2004, 153. http://acta.bibl.u-szeged.hu/5629/ (Letöltés ideje: 2020. 11. 12.) 3 Török

2012, 7. 4 Uo. 16.
} 
kulturális kontextust. ${ }^{4}$ Erre a kijelentésre alapozva vizsgálom a katonai vezetési kultúrát, sajátosságait és összetevõit. Geert Hofstede 2020-ban hunyt el.

Tudományos eredményeit az elmúlt évtizedekben sokan kritizálták, és voltak, akik hibásnak tekintették, de az alapköveket, amelyeket lerakott a szervezeti kultúra kutatása során, építõkövekként lehet tekinteni.

A szervezeti kultúra folytonosságát biztosító és érvényesítõ személy a szerveztek életében a vezetõ. A vezetõ pedig egy személy, akinek saját gondolkodása, tapasztalása és érzelme van, ezek mindegyikének figyelembe vétele szükséges ahhoz, hogy meg tudjuk határozni a vezetési kultúra fogalmát.

A vezetõ mindig sok oldalról vizsgálható. Tanulmányozni lehet a tevékenységét vezetési stílusa vagy akár a felvett vezetõi szerepe alapján. A vezetõ vezetési kultúrájának a vizsgálata és meghatározása nagyon összetett folyamat. Amíg a vezetõ a vezetési stílust egy feladat végrehajtására alkalmazza, a vezetõi szerepet pedig egy beosztás ellátására választja magának, addig a vezetési kultúra megválasztása, felvétele vagy hozzá való igazodása nem ennyire egyértelmû folyamat. Figyelembe kell venni a szervezet sajátosságait, történelmi hagyományait, a benne dolgozók összetételét, a szervezeti célokat és a közösen értelmezett és elfogadott értékeket. Amíg a vezetõ stílusa vagy a választott szerepe változtatható, addig a vezetési kultúra csak nagyon nehezen, és a változásra nagyon sok idõre van szükség. A vezetõi kultúra magába foglalja a szervezeti kultúrát, hisz a szervezetben lévõ vezetõre hatással van, ezért nem tudja magát függetleníteni tõle.

A haderõben a szervezeti kultúra nagyon erõsen van jelen. Hatással van az alegységek életére, és ezáltal a bennük szolgálatot teljesítõkre. Többrétû, és alegységenként is változhat. Gondoljunk arra, hogy egy alakulat névadója okkal lett kiválasztva, hisz hõsies tettei vagy esetleg kapcsolódása az adott egységhez a történelem során bizonyítható. Azonban az is elõfordul, hogy egy egységen belül lévõ alegység, egy másik ikonikus személyt választ magának példaként. Ilyen például a vitéz Szurmay Sándor Budapest Helyõrség Dandár esetében a 32. Nemzeti Honvéd Díszegység, amely a 32-es Gyalogezred jogfolytonosságát megõrzõ ezredszintû szervezet, és ezt a szellemiséget megõrizve örökíti tovább a szellemi és szervezeti kultúráját a régi, Mária Terézia által alapított gyalogezrednek. A nevek és a hadrendi számok, amelyek a katonai egységek élén tálaláhatóak, mind azt mutatják, hogy egy katonai szervezet életében mennyire fontos a hagyományokon és értékeken alapuló szervezeti kultúra. A katonai vezetõkre, akik az adott katonai szervezetben vezetik a katonákat, nagy hatással van ez a szellemiség.

Egy másik szemszögbõl is lehet vizsgálódni, és keresni a vezetõi kultúra jelenségét. A haderõben mindenki számára ismert jelenség a fegyvernemi sovinizmus. Ennek a fogalomnak a legegyszerûbb megközelítési módja, a büszkeség és elfogultság érzése, ami az adott csapathoz vagy testülethez való ragaszkodás legerõsebb jelképe. Gondoljunk a harckocsizókra, a lövészekre, a felderítõkre, a tüzérekre vagy akár a logisztikusokra is. Mindegyik fegyvernemhez történõ tartozás önállóan is egy nagyon erõs összekötõ kapocs a katonai szervezeteken belül. Ezt nevezhetjük fegyvernemi kultúrának is, amelynek sajátossága és erõssége abban rejlik, hogy az adott fegyvernem milyen technikai eszközökkel rendelkezik, milyen harceljárásokat alkalmaz, milyen típusú és mennyire erõs a kiképzési követelménye, vagy éppen milyen speciális képességek jellemzik, amelyeket a katonáknak mind magáénak kell tudnia. A fegyvernemhez való tartozás szocializációjának már kezdeti 
idõszakában mindenkiben rögzül ez a speciális fegyvernemi kultúra, ami az elõbb felsoroltaknak köszönhetõ. Ennek a megvalósulása, fenntartás pedig ismét a vezetõkön keresztül történik.

Nagyon sok oldalról lehetne még vizsgálódni (akár a mûveleti feladatban való részvételek típusa alapján is), de bármely oldalt is állítjuk elõtérbe, ahogy azt korábban is írtam, egy dolog biztosan igaz, a szervezeti és vezetõi kultúra kialakításában, fenntartásában, ápolásában vagy akár modernizálásában a katonai vezetõnek van a legnagyobb szerepe, feladata és felelõssége. Nélküle ez a folyamat elképzelhetetlen.

\section{A vezetési kultúra összetevõi}

A vezetési kultúra nagyon összetett jelenség. Az összetettségébõl következik, hogy annak meghatározáskor sok mindent kell figyelembe venni. Belsõ és külsõ tényezõket egyaránt.

Belsõ tényezõk:

- szervezeti kultúra

- szervezeti profil

- szervezeti célok

- elöljárói célkitûzés

- vezetési stílus

- vezetõi szerep

- vezetõ személyisége- beosztott állomány összetétele Külsõ tényezõk:

- társadalmi megítélés

- társadalomban betöltött szerep

A katonai vezetõre, mint katonára mindkét tényezõ hat. A társadalom részeként vannak önálló gondolatai, nézetei. Hatással is vannak rá ezek a közös vagy különbözõ társadalmiszemléletmódokvagynézetek,demintkatona,alegbefolyásolóbbtényezõszámára a katonai élet sajátosságát jellemzõ szabályrendszer és szemléletmód. ${ }^{3}$ Ennek a specialitásáról Huntington azt mondja: „Haazemberekhosszúidõnátazonosancselekednek,általában jellegzetes és tartós gondolkodási szokásokat fejlesztenek ki. A világgal való, csakis rájuk jellemzõ viszonyuk révén, csakis rájuk jellemzõ módon tekintenek a világra, ami oda vezet, hogy ésszerû magyarázatot találnak viselkedésükre és szerepükre. Ez kiváltképp akkor igaz, amikor a szerep professzionális jellegû. A hivatást szûkszavúbban meghatározottan, intenzivebben és kizárólagosabban mûvelik, és egyértelmûbben elszigeteltek más emberi tevékenységektõl, mint a legtöbb foglalkozásesetében. "6 Jól tükrözõdik az a komplex feladat, elvárás- és befolyásolási rendszer, ami a katonai vezetõkre hat. A vezetési kultúra talán az egyik legmegfoghatatlanabb jelenség, amit nem lehet egy definícióban leírni, és valószínûleg mindenki, aki megpróbálná, hozzá tenne vagy elvenne belõle valamit, ami ugyanúgy értelmessé tenné azt a fogalmat. Ami egyértelmûen leírható tény, hogy létezik és hatást gyakorol a vezetõre, alakítja a szervezetet, ápolja és védi az értékeket és újakat teremt.

\footnotetext{
${ }^{3}$ Farkas 2010, 3. http://www.repulestudomany.hu/kulonszamok/2010_cikkek/Farkas_Imre.pdf (Letöltés ideje: 2020. 11. 13.) 6 Huntington 1994.
} 


\section{Vezetõi gondolkodás és a vezetõi kultúra kapcsolata}

A katonai vezetõi gondolkodást az elmúlt évtizedek alatt, de valójában az elmúlt évszázadban is ugyanazok a jellemzõ hatások változtatták. Új haditechnikák, új harceljárások, új hadszínterek, új kihívások és e hatások megjelenésének vizsgálati eredményei. Sokáig a Clausewitz ${ }^{4}$ által leírtak voltak az alapszabályok, amelyek alkalmazása során volt olyan katonai vezetõ, aki kereste a magyarságot a porosz elvek mellett. Ilyen volt Szombathelyi Ferenc tábornok, aki azt mondta, a háborúra politikailag kevesebbet kell készülni, mint katonailag. Egyértelmûen bizonyítható volt, hogy a magyar katonát nem a gondolkodása, hanem a tettei határozták meg a harcban. ${ }^{5} \mathrm{~A}$ magyar út keresése után az orosz hatás jelenléte sok mindenben változtatta meg a gondolkodást, amely még ma is fellelhetõ a rendszerben. Erre bizonyíték, ha csak arra gondolunk, hogy mai napig vannak ellentmondások fogalom szintjén annak értelmezésében, hogy parancsnok vagy katonai vezetõ. Ezután jelentek meg az amerikai Military Leadership ${ }^{6}$ elvek, amelyek gyökeresen mást képviseltek, mint a korábbiak. A katonai vezetés emberközpontúsága és feladatorientálása kapta a legnagyobb szerepet. Megjelentek azok a követelmények, amelyek ma már megkérdõjelezhetetlenek egy katonai vezetõ számára, mint például példamutatás, hitelesség vagy emberségesség. A vezetõi gondolkodás változása és alkalmazkodása nyomot hagy a vezetõi kultúrában. A történelemben leírt események hatásai egyértelmûen és vitathatatlanul bizonyítják, hogy a magyar katonai vezetõk mindig képesek voltak megújulni, és alkalmazkodó képességük az egyik legnagyobb erényük. A NATO megjelenése olyan mintákat adott a vezetõk számára, amelyek teljesen megváltoztatták az értékeket és a normákat a feladatok végrehajtása során. A vezetõi gondolkodás fejlõdésével együtt változott a vezetési kultúra is. Alkalmazkodott a kor követelményeihez, és vele együtt formálódott megõrizve a múltból azt, ami továbbörökíthetõ érték és építõen hat a jelenben. A katonai vezetési kultúra összetevõi alapján elmondható, hogy a katonai vezetés egyik legmeghatározóbb tényezõje és minõsége határozza meg a vezetés sikerét. Értéke és erõssége abban rejlik, hogy a vezetõ mennyire hisz benne és mennyire tudja közvetítetni azt. Amíg a vezetõi gondolkodás egy olyan folyamat, amelynek célja a problémamegoldás és a lehetséges legmegfelelõbb út megtalálása a feladatok rendszerében, addig a vezetõi kultúra egy olyan komplex jelenség, amely magába foglalja azokat az értékeket, amiket a vezetõ a beosztottjaival együtt közösen teremt vagy ápol a saját cél elérése és az elöljárói szándék megvalósítása érdekében.

\footnotetext{
${ }^{4}$ „A politikum mindig meghatározza a katonai mûveleteket - Clausewitz szavaival élve: A háború a politika más eszközökkel való folytatása csupán. Látjuk tehát, hogy a háború nem pusztán politikai aktus, hanem valóságos politikai eszköz, a politikai érintkezés folytatása, annak más eszközökkel való megvalósítása."

Forgács 2017, 123. http://real.mtak.hu/85130/1/123_Forgacs_A_haboru_es_a_politika _viszonyrendszereAz_igazsagos_haboru_elvetol_az_igazsagos_bekeig.pdf(Letöltés ideje: 2020. 11. 19.)

${ }^{5}$ Kaló 2010, 19-21. https://dea.lib.unideb.hu/dea/bitstream/handle/2437/97153/ertekezes.pdf?sequence=5\&isAllowed=y (Letöltés idõpontja: 2020. 11. 14.)

${ }^{6}$ FM 22-100: Az USA haderejének vezetési doktrínája, amely a Military Leadership vezetési elgondolást tartalmazza. 1953-ban íródott, és egészen 1999-ig frissítették. A jelenleg hatályos koncepciókat tartalmazó vezetési doktrína az USA haderejében, az ADP 6-22, amelynek legfrissebb kiadása 2019-ben jelent meg.
} 


\section{A katonai vezetési kultúra kialakulása}

A vezetési kultúra a katonai vezetõkben sok tényezõ hatása következtében fejlõdik ki. A katonai szocializáció kezdeti idõszaka, az iskolapadban vagy az alapkiképzésen kezdõdik el. Ez a tanulás és a tapasztalás alapjain nyugszik. Késõbb már a megtanult ismeretek alkalmazása és tovább fejlesztése a táptalaja. Minél több külsõ tényezõ hat a katonai vezetõre, annál többrétû lesz a vezetési kultúrája. A kihívások, a szélsõséges helyzetek, a felelõsségvállalás hatása, az ismeretlenség érzete, a helytállás kényszere, mind formálja a vezetõ kultúráját. A felsorolt helyzetek pozitív és negatív tényezõi, mint siker és kudarc megélése az egyik legmeghatározóbb formáló erõ. Egy katonai vezetõtõl elvárható, hogy rendszerszemlélete legyen, minimum három szinttel lejjebb és kettõvel feljebb gondolkozzon, hosszú távra tervezzen, képes legyen a változásra, legyen rugalmas, proaktív, de szabálykövetõ, és mindig a szervezeti célokat részesítse elõnyben a sajátjaival szemben. Az ezeknek való megfelelés önmagában elég elvárás, de ennek az útnak az eredménye, egy sajátos vezetõi kultúra kialakulása. Az, hogy melyik vezetõi milyen vezetési stílusokból merít, vagy milyen vezetõi szerepeket képes felvenni magára, mind ennek a folyamatnak köszönhetõ és eredményezi a vezetési kultúrát. Az egyéni kultúra kialakulásának másik befolyásoló tényezõje a szervezeti kultúra. Minden katona tudat alatt és tudatosan is alkalmazkodik ahhoz a katonai egységhez, ahol szolgál. Felveszi a szervezeti kultúrájának a sajátosságait, és egy idõ után azonosul vele. A katonai vezetõkön ez a hatás még erõsebben érvényesül. A saját véleményüket, meggyõzõdésüket, gondolatvezetésüket alakítja, formálja, de olyan helyzet is elõfordulhat, amikor visszahúzza. Természetesen lehetnek és vannak olyan helyzetek is, amikor a katonai vezetõ nagyon nehezen, vagy egyáltalán nem tudja elfogadni azt a szervezeti kultúrát, amit az adott szervezet képvisel. Ebben a helyzetben a vezetõ két dolgot tehet. Megpróbálja önmagát formálni, a saját kultúráját közelíteni a szervezetihez, hisz az a vezetõ, aki nem fogadja el a saját szervezete mûködési koncepcióját, az nem is tudja megfelelõen képviselni azt, így nem tudja közvetítetni a beosztottak felé, és az általa vezetett alegység hatékonysági mutatói nem lesznek az elvárásoknak megfelelõek.

\section{Katonai vezetési kultúra típusok}

Charles Handy 1986-ban megalkotta a négyféle szervezeti kultúra típust:

- Hatalomkultúra: a hatalom, befolyás, tekintély többnyire egy kézben van, és köré csoportosul. A vezetést a kulcspozíciókban lévõk határozzák meg. Az egyéneket az eredményeik alapján értékelik. A döntéseket az erõviszonyok alapján hozzák.

- Feladatkultúra: itt fontos a teljesítmény és annak az eredménye. A döntési jogkörök megosztottak, az értékelés pedig mindig teljesítmény alapján történik. Fontos a kreativitás és a rugalmasság is.

- Szerepkultúra: fontos összetevõje a szervezeti szerepek. A hatlom forrása a betöltött pozíció. A személyes jellemzõk, ambíciók, újítások, ötletek nem számítanak. Sok munkaköri szabály jellemzi, bürokratikus rend és ügyrend van.

- Személyiségkultúra: nagy szakértelemmel rendelkezõ emberek alapítanak egy szervezetet, így a hatalom csak formálisan van jelen, egyenrangúak, a döntések 
közösen történnek, közös megegyezéssel, nincs vezetõi hierarchia. ${ }^{7}$ Jól látható a kultúratípusok jellemzõi alapján, hogy nincs egy olyan tipikus, amit teljes mértékben illeszteni lehetne a Magyar Honvédség szervezeti kultúrájára. Mindegyikbõl integrálható néhány jellemzõ, és így a négy típus vegyesen van jelen, kiegészülve napjaink sajátosságaival.

Ezekre alapozva a vezetési kultúra kialakulása során a már korábban többször említett komplexitás miatt tapasztalatom alapján a következõ katonai vezetésikultúra-típusok alakultak ki:

\section{Dinamikus}

Vezetési stílusát és szerepét úgy választja meg, hogy a szervezeti kultúrát figyelembe véve, abból a leghasználhatóbb értékeket maga mellé állítva, a saját elképzeléseit menedzser gondolkodással közvetíti a beosztott állomány felé. Azt képviseli, hogy minden helyzetre képesnek kell lenni reagálni a lehetõ leggyorsabb és legprofesszionálisabb módon úgy, hogy mellette a szervezet értékei nem sérülhetnek, és az általa vezetett alegység a legjobb színben tûnjön fel.

\section{Fejlõdõ}

A fiatal vagy nem kiforrott, de fejlõdni képes vezetõkre jellemzõ vezetõi kultúra. Jellemzõje, a meglévõ szervezeti kultúrához való alkalmazkodási út keresése. Saját kultúra kialakulása és igazítása a szervezeti értékekhez és szervezeti célokhoz.

\section{Kényelmes}

Saját egyéniségét megõrizve, a szervezeti célok figyelembevételével úgy alakítja az alegység vezetését, hogy a szervezeti kultúrát elfogadja, azzal azonosulni képes, és közvetíti is a beosztott állomány felé, de ennél többet nem tesz bele. Ennek gyakorlati tükrözõdése, hogy a feladatok elvégzése pontosan határidõre megtörténik, de konstruktív ötletei nincsenek, ez által a szervezeti kultúra fejelõdéséhez nem járul hozzá.

\section{Szervezett}

Minden megtesz azért, hogy a szervezeti célok és a szervezet által képviselt értékek soha ne sérüljenek. Vezetési kultúráját jellemzi a szervezet teljes támogatása és alárendelése annak, ezzel biztosítva gyakorlatban azt, hogy a feladatok tervezése és végrehajtása alegység szinten maradéktalanul történjen. Ezzel biztosítja az egység és alegység szervezeti kultúrájának a fenntartását.

\section{Problémamegoldó}

Különleges vezetési kultúra, amely során a vezetõ azokat a képességeit részesíti elõnyben saját magában és a beosztottjaiban is, amelyek azt segítik elõ, hogy a szervezet a lehetõ leghatékonyabban tudjon reagálni minden helyzetre, feladatra és problémára. Építõen hat a szervezeti kultúrára, hisz ez által sok megoldási javaslat kerül kidolgozásra egy adott helyzetre, amelyek akár új eljárásrendek kidolgozását is eredményezhetik, ennek következményeként pedig, alkalmazásával a többi szervezeti elem is jobban,

\footnotetext{
${ }^{7}$ Kiss, Csillag 2014, 9.
} 
eredményesebben tud mûködni. Így jobban valósulnak meg a szervezeti célok, amelyek ápolják és építik a szervezeti kultúrát.

\section{Ellenálló}

Teljes mértékben tagadja, és nem fogadja el a szervezeti kultúra sajátosságait, ezáltal képtelen alkalmazkodni hozzá, így az általa közvetített kultúra teljesen negatívan hat az általa vezetettekre, ez pedig hatással van a szervezeti és elöljárói célok elérésére.

A vezetési kultúra, a vezetõ személyiségben történõ kialakulása függ attól, hogy milyen típusú vezetési stílusokat, vezetõi szerepeket részesít elõnyben, és azok milyen személyiségi jegyekkel társulnak együtt, valamint függ a szervezeti kultúra jelenlétének erõsségétõl, és attól is, hogy az adott szervezet milyen értékeket részesít elõnyben a beosztott állománynál.

\section{Összegzés}

Tanulmányomban igyekeztem meghatározni a katonai vezetési kultúra fogalmát a saját vezetõi tapasztalatom alapján, értelmezni összetevõit és definiálni azokat a típusokat, amelyek jelen vannak a Magyar Honvédségben. A szervezeti és vezetési kultúra nagyon szoros kapcsolatban állnak egymással. A szervezeti egy komplett rendszer értékeit, hagyományait, meggyõzõdéseit és közös céljait tartalmazza, a vezetõi pedig a saját személyiségébõl, képességébõl merít, alkalmazkodva a szervezeti kultúra egyéni szintre történõ leképezõdésébõl. Látható, hogy hatással vannak egymásra, hisz a szervezeti kultúra közvetítõje a vezetõ így, az közvetlenül a vezetõn keresztül érvényesül. Fontos, hogy a vezetõnek hinnie kell benne, hisz csak akkor tudja hitelesen átadni azokat az értékeket, amik fontosak a szervezeti kultúra megõrzésében és ezzel tud hozzájárulni annak fejlesztéshez. A vezetõi kultúra kialakulása a vezetõben hosszú folyamat és annak megfelelõ, hatékony szintre emelkedése a cél. A kiforrottság a kulcsa annak, hogy a vezetõ már tudatosan tudja közvetíteni a közös értékeket. Ennek az alapja a jó vezetõi kultúra. A vezetõnek hinnie kell abban, amit képvisel, vagy amit közvetít, hisz csak így képes támogatni a szervezetet a mindennapi úton a céljai elérése érdekében. Az alkalmazott gyakorlati megjelenése az alárendelteknél biztosítja a vezetõ számára a közvetítés minõségét.

FELHASZNÁLT IRODALOM

Czeglédi Mihály 2015. A küldetésorientált vezetés kialakulása. Hadtudományi Szemle 8 (3): 89-100. http://epa.oszk.hu/02400/02463/00028/pdf/EPA02463_hadtudomanyi_szemle_2015_03_089-100.pdf

Farkas Imre: A Magyar Honvédség vezetésfelfogása változásainak lehetséges irányai és beépülése a kiképzés rendszerébe. Repüléstudományi Közlemények különszám, 2010. április 16. http://www.repulestudomany.hu/kulonszamok/2010_cikkek/Farkas_Imre.pdf

Forgács Balázs 2017. A háború és a politika viszonyrendszere. In Az igazságos háború elvétõl az igazságos békéig, szerk. Gõcze István, 123-130. Budapest: Dialóg Campus Kiadó. http://real.mtak.hu/85130/1/123_Forgacs_A_haboru_es_a _politika_viszonyrendszereAz_igazsagos_haboru_elvetol_az_igazsagos_be-keig.pdf Huntington, Samuel

P. 1994. A katona és az állam. Budapest: Zrínyi Kiadó - Atlanti Kutató és Kiadó.

Kaló József 2010. Szombathelyi Ferenc a Magyar Királyi Honvéd Vezérkar élén. Doktori $(\mathrm{PhD})$ értekezés, Debreceni Egyetem BTK.

Kiss Csaba, Csillag Sára 2014. Szervezeti kultúra. Budapest: Nemzeti Közszolgálati Egyetem.

Málovics Éva 2004. Szervezeti kultúra és identitás.

In A szociális identitás, az információ és a piac, szerk. Czagány L. és Garai L., 151-167. 
(SZTE Gazdaságtudományi Kar Közleményei 2004)

Szeged: JATE Press. http://acta.bibl.u-szeged.hu/5629/

Török Judit 2012. Kultúrák a szervezeti történetek tükrében, Kultúra összehasonlitó kutatás.

PTE BTK Nyelvtudományi Doktori Iskola Kommunikáció Program, Doktori tézisfüzet. Budapest. 